\title{
How acidic is the lidocaine we are injecting, and how much bicarbonate should we add?
}

\author{
Simon G Frank MD ${ }^{1}$, Donald H Lalonde MD FRCSC ${ }^{2}$
}

SG Frank, DH Lalonde. How acidic is the lidocaine we are injecting, and how much bicarbonate should we add? Can J Plast Surg 2012;20(2):71-74.

BACKGROUND: The infiltration of local anesthetics can be painful, which is likely due, in part, to their acidity. In spite of a Cochrane study that recommended neutralizing lidocaine with bicarbonate to decrease the pain of injection, not many surgeons have adopted the practice, and there are many 'recipes' for how much bicarbonate one should add.

OBJECTIVE: To determine the acidity of lidocaine and the correct ratio of bicarbonate that should be added to neutralize lidocaine to achieve body $\mathrm{pH}$.

METHODS: Fifty samples each of commonly used anesthetics (lidocaine $1 \%$ and $2 \%$, with and without epinephrine $1: 100,000$ ) were obtained and tested for $\mathrm{pH}$. Data were also analyzed according to whether the vials had been previously opened. Ten additional samples of lidocaine $1 \%$ with 1:100,000 epinephrine were titrated against sodium bicarbonate $8.4 \%$ and tested for $\mathrm{pH}$ and the presence of precipitate.

RESULTS: A solution of 1\% lidocaine with 1:100,000 epinephrine had a mean $( \pm$ SD) $\mathrm{pH}$ of $4.24 \pm 0.42$, and $2 \%$ lidocaine with $1: 100,000$ epinephrine had a mean $\mathrm{pH}$ of $3.93 \pm 0.43$. Plain $1 \%$ lidocaine had a $\mathrm{pH}$ of $6.09 \pm 0.16$, and plain $2 \%$ lidocaine had a $\mathrm{pH}$ of $6.00 \pm 0.27$. Epinephrinecontaining solutions were more acidic when they had been previously opened. One per cent lidocaine with epinephrine required $8.4 \%$ sodium bicarbonate at a ratio of $1.1 \mathrm{~mL}: 10 \mathrm{~mL}$ to $1.8 \mathrm{~mL}: 10 \mathrm{~mL}$ to achieve the target tissue $\mathrm{pH}$ of 7.38 to 7.62 .

CONCLUSION: Lidocaine with epinephrine was approximately 1000 times more acidic than subcutaneous tissue. The addition of bicarbonate to the local anesthetic solution is simple to perform and is inexpensive. The proper volume ratio of $8.4 \%$ sodium bicarbonate to $1 \%$ lidocaine with 1:100,000 epinephrine is approximately $1 \mathrm{~mL}: 10 \mathrm{~mL}$. Surgeons should be more aware of the simplicity and value of buffering with bicarbonate to decrease the pain of injection.

\author{
Quelle est l'acidité de la lidocaïne en injection et \\ combien de bicarbonate devrait-on y ajouter?
}

HISTORIQUE : L'infiltration d'anesthésiques locaux peut être dou-
loureuse, ce qui est probablement causé, en partie, par leur acidité. Même
si une étude antérieure a recommandé de neutraliser la lidocaine avec du
bicarbonate pour atténuer la douleur de l'injection, peu de chirurgiens ont
adopté cette pratique, et il existe de nombreuses « recettes » de la quantité de bicarbonate à ajouter.

OBJECTIF : Déterminer l'acidité de la lidocaïne et le bon ratio de bicarbonate à y ajouter pour la neutraliser et parvenir au $\mathrm{pH}$ corporel.

MÉTHODOLOGIE : Les chercheurs ont obtenu 50 échantillons de chacun des anesthésiques couramment utilisés (lidocaïne $1 \%$ et $2 \%$, avec et sans dilution d'adrénaline 1:100 000) et en ont vérifié le pH. Ils ont également analysé les données pour vérifier si les fioles avaient été ouvertes au préalable. Ils ont titré dix échantillons supplémentaires de lidocaïne $1 \%$ contenant de l'adrénaline 1:100 000 à l'aide de bicarbonate de sodium 8,4\%, puis ont vérifié le $\mathrm{pH}$ et la présence de précipité.

RÉSULTATS : Une dilution 1:100 000 de lidocaïne $1 \%$ contenant de

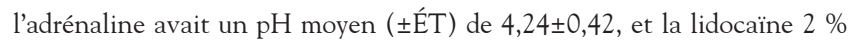

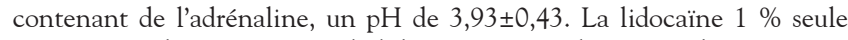
avait un $\mathrm{pH}$ de $6,09 \pm 0,16$, et la lidocaine $2 \%$ seule, un $\mathrm{pH}$ de $6,00 \pm 0,27$. Les solutions contenant de l'adrénaline étaient plus acides lorsqu'elles avaient été ouvertes au préalable. De la lidocaïne $1 \%$ contenant de l'adrénaline devait contenir $8,4 \%$ de bicarbonate de sodium à une dilution de 1,1:10 à 1,8:10 pour parvenir au $\mathrm{pH}$ tissulaire ciblé de 7,38 à 7,62.

CONCLUSION : La lidocaïne contenant de l'adrénaline était environ 1000 fois plus acide que les tissus sous-cutanés. Il est simple et peu coûteux d'ajouter du bicarbonate à une solution anesthésique locale. La bonne proportion entre le volume de bicarbonate de sodium $8,4 \%$ et la lidocaïne $1 \%$ accompagnée d'adrénaline 1:100 000 est d'environ 1:10. Les chirurgiens devraient connaître la simplicité et la valeur d'utiliser une solution tampon de bicarbonate pour atténuer la douleur de l'injection.

Key Words: Anesthetics; Epinephrine; Lidocaine; Local; Pain of injection; $\mathrm{pH}$

The infiltration of local anesthetics can be painful, and some of this 1 pain may be attributed to the acidity of the anesthetic solution (1). In spite of the fact that a Cochrane study recommended buffering lidocaine with bicarbonate to decrease the pain of injection (2), the use of bicarbonate with lidocaine has only been adopted by a minority of practicing surgeons.

One of the possible reasons that surgeons do not use buffered lidocaine is that most hospital pharmacies only premix bicarbonate and lidocaine without epinephrine, which is not as useful as buffered solutions containing epinephrine. In addition, there is a lack of knowledge about how exactly one is required to mix bicarbonate with the local anesthetic and what ratio of the mixture is ideal.

The present study aimed to measure the $\mathrm{pH}$ of commonly used lidocaine-containing anesthetic agents available at our institutions and to validate the proper concentration of bicarbonate that should be added to lidocaine with epinephrine to neutralize its $\mathrm{pH}$. The present article also aims to generate awareness among surgeons about how simple and inexpensive it is to mix bicarbonate with lidocaine to eliminate the acidity-related pain of local anesthetic injection.

\section{METHODS}

Commercially available solutions of $1 \%$ and $2 \%$ lidocaine, with and without epinephrine 1:100,000 were obtained (AstraZeneca Inc, Canada; Alveda Pharma, Canada). These were collected from various settings throughout a tertiary care institution (Dalhousie University, Halifax, Nova Scotia; Saint John, New Brunswick) to capture the possible effects of prolonged storage, previously opened bottles or improper storage conditions, to simulate true clinical use conditions. A total of 200 samples were collected (50 samples of each solution) from a variety of lots and ranging in expiration dates. Note was made of whether each multiuse vial was factory sealed or had been opened previously. The $\mathrm{pH}$ of each sample was measured using a temperaturecompensating $\mathrm{pH}$ meter (Model 98128, Hanna Instruments, Canada) with a resolution of 0.01 and a mean $( \pm$ SD) accuracy \pm 0.05 .

To determine the proper concentration of bicarbonate for neutralization, additional samples of $1 \%$ lidocaine with 1:100,000 epinephrine were obtained, along with samples of $8.4 \%$ sodium bicarbonate (Hospira, Canada). Ten samples of each were collected. Aliquots of sodium bicarbonate $(0.5 \mathrm{~mL})$ were added to $20 \mathrm{~mL}$ of lidocaine and

\footnotetext{
${ }^{1}$ Division of Plastic and Reconstructive Surgery, Dalhousie University, Halifax, Nova Scotia; ${ }^{2}$ Division of Plastic and Reconstructive Surgery,

Dalhousie University, Saint John, New Brunswick

Correspondence: Dr Donald H Lalonde, Division of Plastic and Reconstructive Surgery, Dalhousie University, Hilyard Place, Suite C204 - 600

Main Street, Saint John, New Brunswick E2K 1J5. Telephone 506-639-2526, fax 506-652-8042, e-mail labtrio@nbnet.nb.ca
} 


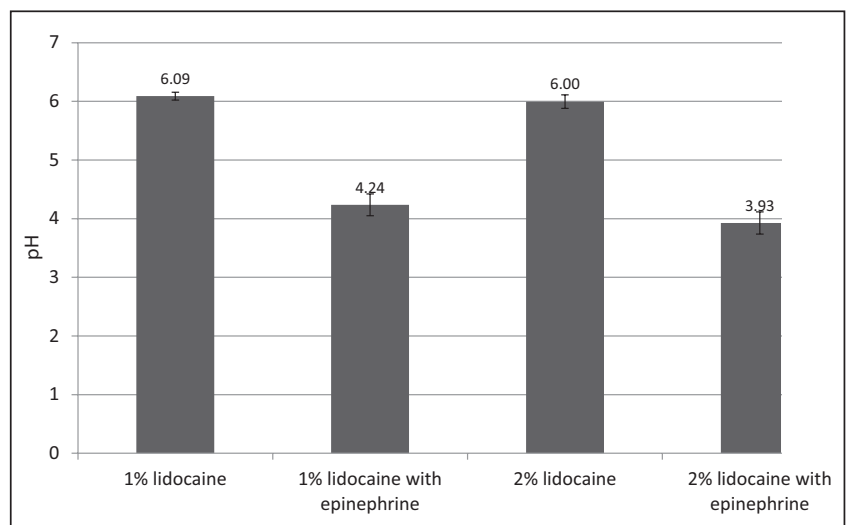

Figure 1) $\mathrm{pH}$ of lidocaine $1 \%$ and 2\%, with and without 1:100,000 epinephrine. Error bars represent $95 \%$ CIs

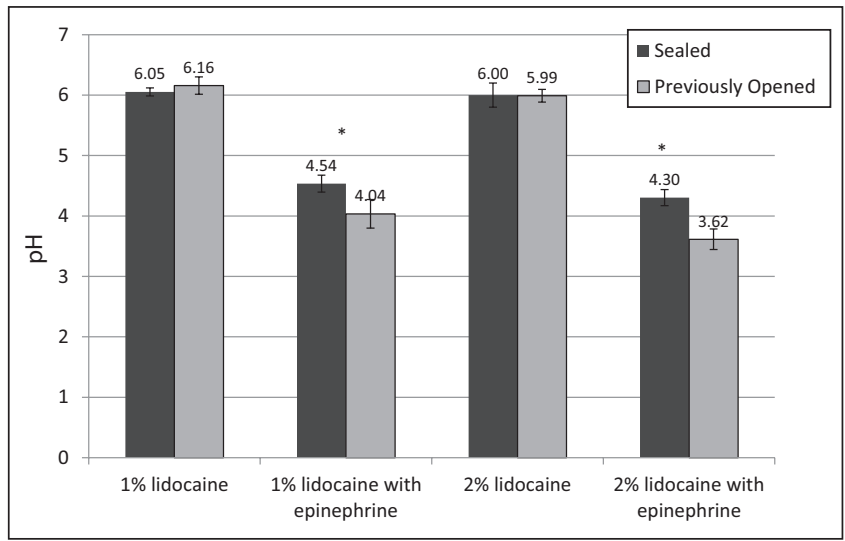

Figure 2) pH of factory sealed versus previously opened multiuse vials of lidocaine. Error bars represent $95 \% \mathrm{CIs}$

$\mathrm{pH}$ was recorded after mixing. After each addition, samples were analyzed against light and dark backgrounds to check for the presence of precipitate.

Statistical analysis was performed using Microsoft Excel (Microsoft Corporation, USA). Student's $t$ tests were used to compare means. Statistical significance was set at $\mathrm{P}<0.05$. Results are presented as mean \pm SD

\section{RESULTS}

A solution of $1 \%$ lidocaine with 1:100,000 epinephrine had a mean $\mathrm{pH}$ of $4.24 \pm 0.42$, and $2 \%$ lidocaine with 1:100,000 epinephrine had a mean $\mathrm{pH}$ of $3.93 \pm 0.43$. Plain $1 \%$ lidocaine had a mean $\mathrm{pH}$ of $6.09 \pm 0.16$, and plain $2 \%$ lidocaine had a mean $\mathrm{pH}$ of $6.00 \pm 0.27$ (Figure 1). The epinephrine-containing solutions were more acidic than their plain counterparts by an absolute magnitude of 1.85 for $1 \%$ lidocaine and 2.07 for $2 \%$ lidocaine $(\mathrm{P}<0.05)$. There was no significant difference in the $\mathrm{pH}$ between the $1 \%$ and $2 \%$ solutions.

Comparison of factory-sealed multidose vials with those that had been previously opened revealed no difference in $\mathrm{pH}$ in plain $1 \%$ solutions $(6.05 \pm 0.12$ versus $6.16 \pm 0.19$, respectively) nor plain $2 \%$ solutions $(6.00 \pm 0.34$ versus $5.99 \pm 0.16)(P>0.05)$ (Figure 2$)$. Previously opened epinephrine-containing $1 \%$ lidocaine solutions were more acidic than those that were factory sealed $(\mathrm{pH} 4.04 \pm 0.42$ versus $\mathrm{pH} 4.54 \pm 0.20$, respectively [difference $=0.50$ ]) as were epinephrine-containing $2 \%$ solutions $(\mathrm{pH} 3.62 \pm 0.29$ versus $\mathrm{pH} 4.30 \pm 0.21$ [difference $=0.69$ ]) $(\mathrm{P}<0.05)$.

Figure 3 represents a titration curve of 1\% lidocaine with 1:100,000 epinephrine versus $8.4 \%$ sodium bicarbonate. A ratio of $1.1 \mathrm{~mL}: 10 \mathrm{~mL}$ achieved a mean $\mathrm{pH}$ of $7.38 \pm 0.12$. A dilution of $1.8 \mathrm{~mL}: 10 \mathrm{~mL}$ achieved a mean $\mathrm{pH}$ of $7.62 \pm 0.12$. No precipitate was identified in any samples in concentrations up to $2 \mathrm{~mL}: 10 \mathrm{~mL}$, which produced a mean

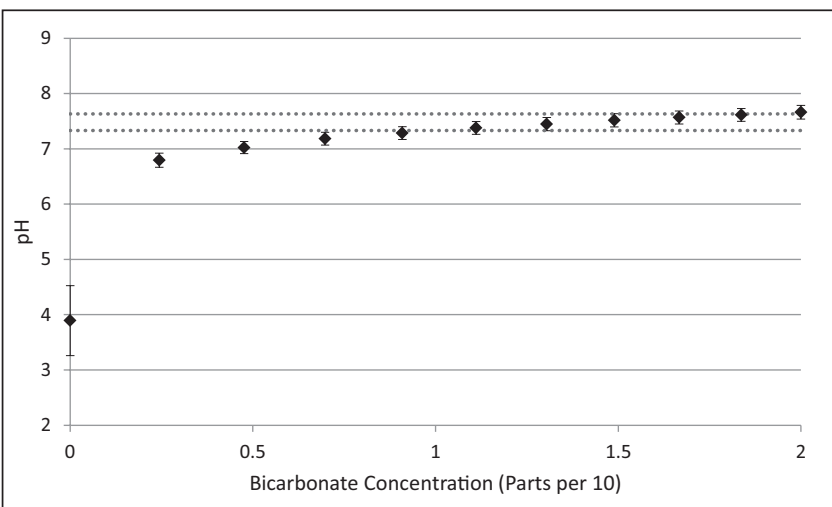

Figure 3 ) Titration curve of $8.4 \%$ sodium bicarbonate against $1 \%$ lidocaine with 1:100,000 epinephrine. Dotted lines represent tissue $\mathrm{pH}$ (7.38 to 7.62) (3). Error bars represent $95 \%$ CIs

$\mathrm{pH}$ of 7.66. SDs were low across the titration curve once sodium bicarbonate was introduced $(<0.13$ at all data points).

\section{DISCUSSION}

One per cent lidocaine with 1:100,000 epinephrine at our institution was found to be a factor of 1000 more acidic than subcutaneous tissue, the latter having a $\mathrm{pH}$ of approximately 7.3 to 7.6 (3). Epinephrinecontaining solutions (approximate $\mathrm{pH} 4$ ) were markedly more acidic than lidocaine without epinephrine (approximate $\mathrm{pH}$ 6). We also verified that the proper volume ratio of $8.4 \%$ bicarbonate to $1 \%$ lidocaine with 1:100,000 epinephrine is approximately $1 \mathrm{~mL}: 10 \mathrm{~mL}$ to neutralize the $\mathrm{pH}$ to 7.4 , as was previously suggested by Momsen et al (4).

In spite of the fact that a Cochrane study recommended buffering lidocaine with bicarbonate to decrease the pain of injection and that buffering has been found to be useful in carpal tunnel surgery, the use of bicarbonate-buffered lidocaine with epinephrine has only been adopted by a minority of practicing surgeons $(1,5)$.

We found that the ratio of lidocaine and bicarbonate required to achieve a tissue $\mathrm{pH}$ of 7.3 to 7.6 was between $1.1 \mathrm{~mL}: 10 \mathrm{~mL}$ and $1.8 \mathrm{~mL}: 10 \mathrm{~mL}$, although a ratio of $1 \mathrm{~mL}: 10 \mathrm{~mL}$ produced nearly the same $\mathrm{pH}$ (3). Our data indicate that there is no risk of precipitate forming at these concentrations. For practical purposes, we recommend mixing $10 \mathrm{~mL}$ of $1 \%$ lidocaine with $1: 100,000$ epinephrine with $1 \mathrm{~mL}$ of $8.4 \%$ sodium bicarbonate solution. Clarifying the proper mixture ratio is important because there have been many mixtures of different concentrations of lidocaine and bicarbonate advocated in the literature. For instance, the recent Cochrane review included studies that reported ratios of sodium bicarbonate ranging from $1 \mathrm{~mL}: 2 \mathrm{~mL}$ to $1 \mathrm{~mL}: 33 \mathrm{~mL}(1,6,7)$.

There are two ways by which surgeons can obtain buffered lidocaine. The first, and most useful, is that surgeons buffer their own lidocaine with a solution such as $8.4 \%$ sodium bicarbonate (Figure 4), which is readily available and costs less than CAD $\$ 5$ per bottle. It is easily mixed just before injection and can be mixed in a syringe or in the bottle of lidocaine. It is a fortunate coincidence that a $10 \mathrm{~mL}$ syringe holds $11 \mathrm{~mL}$ of liquid, and that a $20 \mathrm{~mL}$ syringe holds $22 \mathrm{~mL}$ of liquid. In practice, we usually draw $1 \mathrm{~mL}$ of bicarbonate and then $10 \mathrm{~mL}$ of $1 \%$ lidocaine with $1: 100,000$ epinephrine into a $10 \mathrm{~mL}$ syringe so the two solutions are mixed to a total of $11 \mathrm{~mL}$ of volume in the $10 \mathrm{~mL}$ syringe, resulting in a ratio of $1 \mathrm{~mL}: 10 \mathrm{~mL}$ (Figure 5).

The second way to obtain buffered lidocaine is to have the hospital pharmacy buffer it. However, in our hospitals, the pharmacy only prepares buffered $1 \%$ lidocaine solution without epinephrine. No prebuffered epinephrine-containing solutions are available. From our data, it is clear that the potential benefits of neutralizing a plain solution would be less than the benefits of neutralizing an epinephrinecontaining solution based on the approximately 70 -fold increased acidity of the latter ( $\mathrm{pH} 4.24$ versus $\mathrm{pH} 6.09$ for $1 \%$ solutions). 


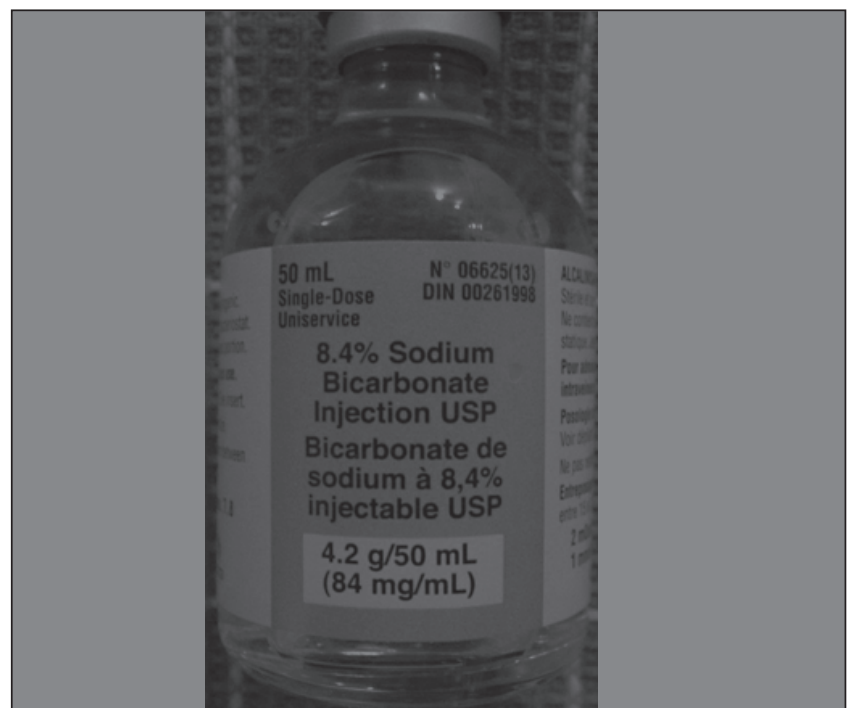

Figure 4) Bicarbonate $8.4 \%$ is readily available and costs less than CAD $\$ 5$ per bottle. It has no preservative, and is therefore usually discarded at the end of the day

Furthermore, buffered lidocaine without epinephrine is not very useful in our practice. Since the death of the epinephrine myth and the validation of the phentolamine antidote to epinephrine vasoconstriction, we seldom use lidocaine without epinephrine in finger and hand surgery, or in any other part of the body (8-11). The epinephrine increases the duration of lidocaine's anesthetic effect and decreases surgical bleeding (12).

\section{REFERENCES}

1. Vossinakis IC. Re: Reduction in pain associated with open carpal tunnel decompression. J Hand Surg Br 2001;26:503-4.

2. Cepeda MS, Tzortzopoulou A, Thackrey M, Hudcova J, Arora Gandhi P, Schumann R. Adjusting the $\mathrm{pH}$ of lidocaine for reducing pain on injection. Cochrane Database Syst Rev 2010;(12):CD006581.

3. Gerweck LE, Seetharaman K. Cellular $\mathrm{pH}$ gradient in tumor versus normal tissue: Potential exploitation for the treatment of cancer. Cancer Res. 1996;56:1194-8

4. Momsen OH, Roman CM, Mohammed BA, Andersen G. Neutralization of lidocaine-adrenaline. A simple method for less painful application of local anesthesia. Ugeskr Laeger 2000;162:4391-4.

5. Lalonde DH. "Hole-in-one" local anesthesia for wide-awake carpal tunnel surgery. Plast Reconstr Surg 2010;126:1642-4.

6. Gershon RY, Mokriski BK, Matjasko MJ. Intradermal anesthesia and comparison of intravenous catheter gauge. Anesth Analg 1991;73:469-70.

7. Sapin P, Petrozzi R, Dehmer GJ. Reduction in injection pain using buffered lidocaine as a local anesthetic before cardiac catheterization. Cathet Cardiovasc Diagn 1991;23:100-2.

8. Thomson CJ, Lalonde DH, Denkler KA, Feicht AJ. A critical look at the evidence for and against elective epinephrine use in the finger. Plast Reconstr Surg 2007;119:260-6.

9. Fitzcharles-Bowe C, Denkler K, Lalonde D. Finger injection with high-dose $(1: 1,000)$ epinephrine: Does it cause finger necrosis and should it be treated? Hand (N Y) 2007;2:5-11.

10. Lalonde D, Bell M, Benoit P, Sparkes G, Denkler K, Chang P. A multicenter prospective study of 3,110 consecutive cases of elective epinephrine use in the fingers and hand: The Dalhousie project clinical phase. J Hand Surg Am 2005;30:1061-7.

11. Nodwell T LD. How long does it take phentolamine to reverse adrenaline-induced vasoconstriction in the finger and hand?

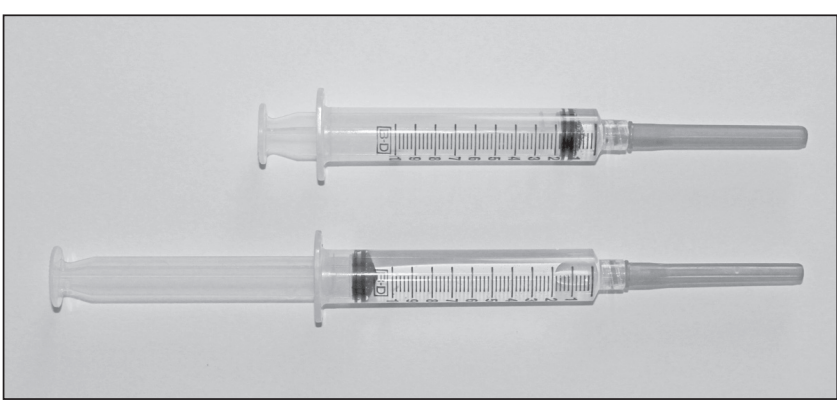

Figure 5) Syringes with $1 \mathrm{~mL} \mathrm{8.4 \%} \mathrm{bicarbonate} \mathrm{(top)} \mathrm{and} \mathrm{with} 1 \mathrm{~mL}$ sodium bicarbonate and 10 additional $\mathrm{mL} 1 \%$ lidocaine with 1:100,000 epinephrine for a total of $11 \mathrm{~mL}$ of solution (bottom)

It is interesting to note that much of the existing literature regarding the buffering of lidocaine to reduce pain involves lidocaine solutions without epinephrine (13-19). The addition of epinephrine and the necessary preservatives decreases the $\mathrm{pH}$ of the solution and, therefore, increases the potential beneficial effect of buffering $(13,14$, 20,21). The literature should be viewed with this in mind, and clinical application and future research tailored accordingly.

\section{SUMMARY}

Lidocaine with epinephrine is very acidic compared with subcutaneous tissue. The addition of $8.4 \%$ bicarbonate at a volume ratio of $1 \mathrm{~mL}: 10 \mathrm{~mL}$ neutralizes the acidity of $1 \%$ lidocaine with 1:100,000 epinephrine. Neutralizing the $\mathrm{pH}$ of lidocaine has been previously shown to decrease the pain of injection. It is simple, inexpensive and can easily be performed by surgeons shortly before local anesthetic injection.

A prospective randomized blinded study: The Dalhousie project experimental phase. Can J Plast Surg 2003;11:187.

12. Thomson CJ, Lalonde DH. Randomized double-blind comparison of duration of anesthesia among three commonly used agents in digital nerve block. Plast Reconstr Surg 2006;118:429-32.

13. Parham SM, Pasieka JL. Effect of $\mathrm{pH}$ modification by bicarbonate on pain after subcutaneous lidocaine injection. Can J Surg 1996;39:31-5.

14. Watts AC, Gaston P, Hooper G. Randomized trial of buffered versus plain lidocaine for local anaesthesia in open carpal tunnel decompression. J Hand Surg Br 2004;29:30-1.

15. Bartfield JM, Crisafulli KM, Raccio-Robak N, Salluzzo RF. The effects of warming and buffering on pain of infiltration of lidocaine. Acad Emerg Med. 1995;2:254-8.

16. Palmon SC, Lloyd AT, Kirsch JR. The effect of needle gauge and lidocaine $\mathrm{pH}$ on pain during intradermal injection. Anesth Analg 1998;86:379-81.

17. Xia Y, Chen E, Tibbits DL, Reilley TE, McSweeney TD. Comparison of effects of lidocaine hydrochloride, buffered lidocaine, diphenhydramine, and normal saline after intradermal injection. J Clin Anesth 2002;14:339-43.

18. Serour F, Levine A, Mandelberg A, Ben Yehuda Y, Boaz M, Mori J. Alkalinizing local anesthetic does not decrease pain during injection for dorsal penile nerve block. J Clin Anesth 1999;11:563-6.

19. Ririe DG, Walker FO, James RL, Butterworth J. Effect of alkalinization of lidocaine on median nerve block. Br J Anaesth 2000;84:163-8.

20. Morris R, McKay W, Mushlin P. Comparison of pain associated with intradermal and subcutaneous infiltration with various local anesthetic solutions. Anesth Analg 1987;66:1180-2.

21. Dejong RH, Cullen SC. Buffer-demand and ph of local anesthetic solutions containing epinephrine. Anesthesiology 1963;24:801-7. 